\title{
Analisis Implementasi Panel Surya pada Pelanggan Listrik 900W
}

\author{
Sepdian $^{1}$ dan Maizal Isnen ${ }^{2}$ \\ ${ }^{1}$ Prodi Teknik Listrik dan ${ }^{2}$ Elektronika, Politeknik Jambi \\ Jl. Lingkar Barat II, Lorong Veteran, Kota Jambi 36128 \\ e-mail: sepdian@politeknikjambi.ac.id
}

\begin{abstract}
Abstrak - Penerapan energi baru terbarukan (EBT), seperti energi surya, menjadi salah satu cara untuk meningkatkan ketercapaian terget serapan EBT 23\% di tahun 2025 secara nasional. Provinsi Jambi yang terletak -1,6o LU dari garis ekuator memiliki potensi yang besar akan energi surya, yakni $4,59 \mathrm{kWh} / \mathrm{m} 2 / \mathrm{hari}$. Untuk itu, sebagai salah satu cara untuk mendorong masyarakat mulai melakukan peralihan dari energi listrik konvensional menuju energi terbarukan, dibangun suatu sistem tenaga surya yang difungsikan sebagai energi cadangan, guna mengatasi disaat terjadinya pemadaman listrik. Rancangan ini dibangun untuk diterapkan pada pelanggan listrik berdaya 900 watt. Hasil pengujian dalam skala laboatorium, dengan menggunakan panel surya 100Wp dan baterai 70Ah, diperoleh potensial energi yang dihasilkan sebesar $0,32 \mathrm{kWh}$ sampai dengan $0,74 \mathrm{kWh}$ per hari. Waktu pengisian baterai diperoleh selama 720 menit dengan daya pengisian PV sebesar 70 watt. Sementara itu, dengan menggunakan daya $500 \mathrm{~W}$, diperoleh waktu pengosongan baterai selama 100 menit. Penerapan ini, diperoleh potensi penghematan energi listrik sebesar $6 \%$ sampai $15 \%$ dari total 4 ,9kWh energi yang dibutuhkan per hari. Implementasi sistem energi surya sebagai energi cadangan ini selain mampu menanggulangi disaat terjadi pemadaman listrik, juga mengurangi ketergantungan terhadap energi listrik konvensional.
\end{abstract}

Kata kunci: Photovoltaic, energy backup, RETscreen, efisiensi listrik

Abstract - The application of renewable energy $(R E)$, such as solar energy, is such a way to increase the implementation of renewable energy for $23 \%$ in 2025 nationally. Jambi Province which is located -1.60 NL from the equator has a great potential for solar energy, which is $4.59 \mathrm{kWh} / \mathrm{m} 2 /$ day. For this reason, to encourage people startAX making a transition from conventional electricity to renewable energy, a solar power system was built for energy backup to overcome sudden power cut. This implementation designed for electricity consumer with contract of 900 watts. The test results on a laboratory scale, using $100 \mathrm{Wp}$ solar panels and 70Ah batteries, obtained the potential energy generated is from 0.32 $\mathrm{kWh}$ to $0.74 \mathrm{kWh}$ per day. The battery charging time is obtained for 720 minutes with a $P V$ charging power of 70 watts. Meanwhile, using 500W of power, the battery discharge time is obtained for 100 minutes. This application has a potential saving of $6 \%$ to $15 \%$ of the total energy required per day. The implementation of the solar energy system not only functioning as energy backup but also to couple when power cut occurs, and it also reduces dependence on conventional electrical energy.

Keywords: Photovoltaic, energy backup, RETscreen, electrical efficiency

\section{PENDAHULUAN}

Kebutuhan akan energi listrik belakangan ini terus meningkat. Peningkatan tersebut dipengaruhi faktor peningkatan jumlah populasi, laju industrialisasi maupun urbanisasi. Dibandingkan dengan pertumbuhan populasi global, dalam kurun waktu 15 sampai 20 tahun mendatang, konsumsi energi tumbuh jauh lebih cepat dan berpotensi berlipat ganda. Sementara itu, cadangan sumber energi konvensional, seperti bahan bakar fosil, mulai mengalami penipisan. Selain jumlah pasokan yang menipis dan jumlah permintaan yang meningkat, adanya efek negatif dari bahan bakar fosil, seperti efek gas rumah kaca, menjadi tantangan bagi dunia saat ini untuk menyediakan pasokan energi yang berkelanjutan dan bersih [1].

Di Indonesia sendiri, kebergantungan terhadap energi fosil saat ini masih tinggi, yakni sampai dengan $95 \%$. Dengan kata lain, pemanfaatan energi baru terbarukan
(EBT) masih cukup jauh dari target pencapaian $23 \%$ di tahun 2025, sebagai mana tertuang dalam Rencana Umum Energi Nasional (RUEN) [2].

Pembangkit listrik tenaga surya di Indonesia menjadi salah satu yang memiliki potensi paling tinggi. khususnya penggunaan listrik rumah tangga, penggunaan photo voltaic (PV) menjadi salah satu pilihan yang paling efektif. Akan tetapi, energi puncak yang dihasilkan PV pada siang hari tidak dapat digunakan secara optimal, dikarenakan jumlah beban yang sedikit disiang hari. Sehingga, puncak penggunaan beban lebih banyak terjadi di sore dan malam hari yang tidak dapat diakomodir oleh PV secara langsung. Disamping itu Intermitensi PV bergantung pada siklus siang dan malam maupun kondisi cuaca langsung. Sehingga, keberadaan energi storage, atau baterai, sangat diperlukan [3]. 


\section{STUdi PUSTAKA}

Secara geografis, Provinsi Jambi terletak pada $-1,6^{\circ}$ lintang utara, dan $103,6^{\circ}$ bujur timur, yang artinya cukup dekat dengan garis khatulistiwa. Kondisi ini memberikan efek yang Mengacu pada data RETScreen, Provinsi Jambi memiliki potensi pancaran sinar matahari yang cukup baik. Mengacu pada data RETScreen, Provinsi Jambi memiliki potensi pancaran sinar matahari sebagai berikut:

Tabel 1. Potensi energi surya di Provinsi Jambi

\begin{tabular}{cc}
\hline Bulan & $\begin{array}{c}\text { Radiasi matahari } \\
(\mathrm{kWh} / \mathrm{m} 2 / \mathrm{d})\end{array}$ \\
\hline Januari & 4.19 \\
Februari & 4.74 \\
Maret & 4.75 \\
April & 4.78 \\
Mei & 4.64 \\
Juni & 4.56 \\
Juli & 4.49 \\
Agustus & 4.75 \\
September & 4.83 \\
Oktober & 4,66 \\
November & 4.5 \\
Desember & 4.31 \\
\hline Rata-rata & $\mathbf{4 . 5 9}$ \\
\hline
\end{tabular}

Khususnya di Provinsi Jambi, potensi energi listrik yang dihasilkan dari matahari adalah $4,59 \mathrm{~kW} / \mathrm{m}^{2} /$ hari. Potensi tersebut belum termanfaatkan secara optimal saat ini, dilihat dari masih banyaknya ketergantungan masyarakat akan energi listrik negara yang bersumber dari energi fosil.

Tidak dapat dipungkiri berbagai aspek menjadi pertimbangan, misalnya nilai investasi awal, kualitas maupun keberlangsungan energi listrik. Disisi lain, layanan penyedia energi listrik tidak selamanya baik. Dibeberapa daerah masih sering mengalami pemadaman, kedipan (flicker), maupun tegangan listrik yang kurang stabil [4]. Hal ini tentu menimbulkan keluhan pada sisi pelanggan.

Integrasi sistem PV untuk penggunaan listrik domestik (rumah tangga) pada umumnya difungsikan sebagai energy backup disaat terjadinya pemadaman listrik. Fungsi ini sama halnya dengan peran UPS (uninterruptible power supply) untuk menjaga beban yang terhubung tetap menyala disaat terjadinya pemadaman [5]. Dalam implementasinya dapat dimanfaatkan sebagai alat untuk mengurangi ketergantungan terhadap energi listrik konvensional maupun untuk meningkatkan efisiensi energi listrik. Dalam hal meningkatkan efisiensi penggunaan energi listrik diperlukan perangkan controller sebagaiman yang pernah di jabarkan dalam [6], dengan menerapkan machine learning guna menentukan prioritas daya yang diperlukan.

Dalam penelitian kali ini, dilakukan pengamatan terhadap performa penggunaan panel PV dengan energy storage baterai yang dikombinasikan dengan listrik konvensional pada pelanggan PLN dengan daya 900 VA untuk penggunaan rumah tinggal dan melihat peluang penghematan energi yang dapat diperoleh dari implementasi ini.

\section{METODE}

\section{A. Estimasi Kebutuhan Energi Listrik Rumah}

Dalam penelitian ini digunakan referensi kebutuhan listrik rumah tangga pada pelanggan listrik dengan daya tersambung 900 watt. Pelanggan dengan skema tarif ini masuk dalam kategori R-1M, dengan biaya per kWh sebesar $\mathrm{Rp}$ 1.352. Dengan rata-rata pembayaran listrik per bulan sebesar Rp 200.000,- maka, jumlah daya listrik yang terpakai dalam satu bulan adalah $147 \mathrm{kWh}$. Dengan demikian, rata-rata kebutuhan energi listrik per hari berada pada kisaran $4,9 \mathrm{kWh}$.

\section{B. Perancangan Sistem}

Perancangan sistem energi cadangan ini dibangun dengan mempertimbangkan kegunaan sebagai berikut:

1. Digunaan sebagai energy backup disaat terjadi pemadaman listrik. Untuk penerapan ini, sistem dibangun dengan dilengkapi electric switching system yang akan bekerja secara otomatis disaat terjadi pemadaman listrik seketika.

2. Digunakan sebagai penghemat energi listrik [5], mengurangi dependency terhadap penyedia listrik konvensional.

Spesifiaksi panel PV yang digunakan yakni berjenis polycrystaline $100 \mathrm{Wp}$, dengan spesifikasi maksimum tegangan keluaran (Vmp) sebesar 17,4 volt. Arus maksimum yang dapat dihasilkan (Imp) adalah 5,75 ampere, sehingga daya maksimum yang mampu diperoleh yakni 100,05 watt atau dapat dibulatkan menjadi 100watt. Panel surya ini memiliki dimensi panjang $100 \mathrm{~cm}$ dan lebar $67 \mathrm{~cm}$, sehingga luas permukaannya adalah $6700 \mathrm{~cm}^{2}$ atau $0,67 \mathrm{~m}^{2}$.

Sementara itu, energy storage yang digunakan adalah baterai, dengan spesifikasi yakni jenis baterai Lead Acid battery, dengan tegangan maksimal sebesar 12,7 volt, dan kapasitas baterai $70 \mathrm{Ah}$.

Dalam menentukan kebutuhan inverter dapat mengacu pada total daya yang dibutuhan per hari. Daya inverter yang dipilih harus lebih besar 25-30\% dari kebutuhan daya yang diperlukan per hari [7]. Jika mengikuti teori ini maka inverter yang disiapkan setidaknya memiliki kapasitas 1125 watt sampai 1170 watt. Dalam penelitian kali ini digunakan inverter dengan daya 1000 watt disebabkan perbedaan energi yang perlukan tidak berbeda terlalu signifikan, yakni $11 \%$ dari daya maksimal yang diperlukan.

Pada pengisian daya baterai, digunakan solar charger controller. Solar Charge Control (SCC) juga sering disebut Battery Controller Unit $(B C U)$ merupakan perangkat yang berfungsi mengatur tegangan dan arus dari solar sel ke baterai sebagai proses pengisian [8]. SCC yang digunakan memiliki spesifikasi input $12 / 24$ volt, dengan arus maksimum dapat mencapai 30A. Berikut diagram blok sistem pembangkit listrik tenaga surya sebagai energy backup rumah tinggal, Gambar 1. 


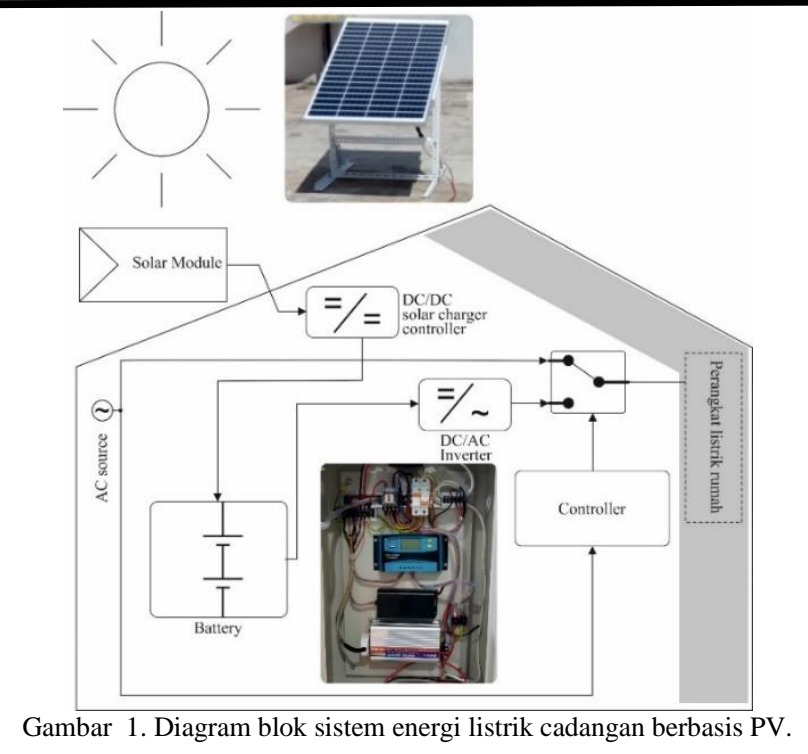

Pada bagian luar rumah, panel surya ditempatkan di bagian atap (rooftop) guna memperoleh paparan sinar matahari yang paling optimal. Adapun sudut kemiringan disesuaikan dengan letak geografis provinsi jambi, yakni $1,6^{\circ}$ mengarah ke utara, sebagaimana yang pernah di bahas pada [9] dan [10].

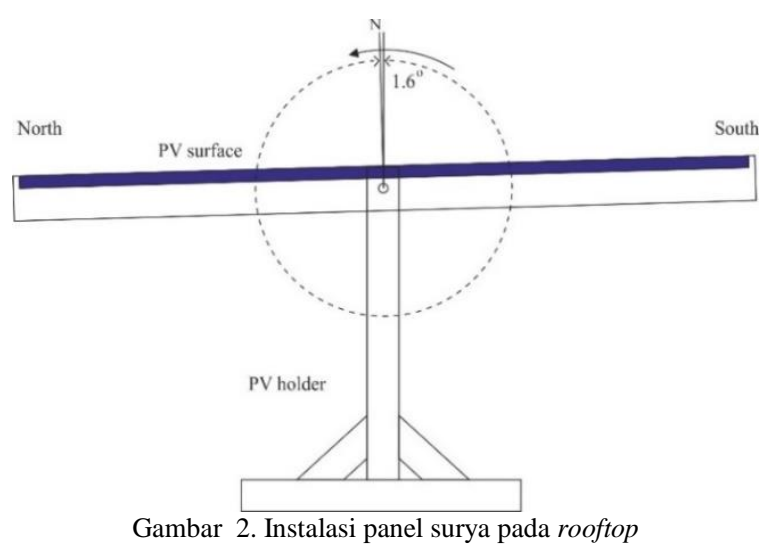

Sementara itu, komponen lainnya seperti solar charger controller, baterai, inverter maupun controller ditempatkan pada ruangan.

\section{Estimasi Daya Dihasilkan PV}

Untuk menentukan daya yang mampu dihasilkan oleh $\mathrm{PV}$, dapat mengacu pada persamaan berikut:

$$
\text { Daya }(\text { watt })=\frac{\text { Daya Puncak PV (watt) }}{P G F}
$$

dimana, PGF adalah Panel Generation Factor $=0,32$, [11]. Jika digunakan satu buah panel surya dengan daya punjak $100 \mathrm{Wp}$, maka akan dihasilkan daya listrik sebesar 32watt. Dengan demikian, akan diperoleh energi listrik 320 watt.jam jika durasi pancaran sinar matahari per hari adalah 10 jam.

\section{HASIL DAN PEMBAHASAN}

\section{A. Pengukuran energi panel surya}

Berikut ditampilkan hasil pengukuran rata-rata tegangan maupun daya yang dihasilkan panel surya dalam satu hari.

Grafik pada gambar 2 diatas merupakan hasil pengukuran open circuit voltage dan potensi daya yang dihasilkan oleh panel PV 100Wp. Estimasi energi listrik yang dihasilkan panel surya melalui grafik dapat dihitung dengan cara menghitung luas area dibawah grafik.

1. Pukul 06.00 - 08.00, dengan daya maksimum 70 watt, maka kapasitas listrik yang dihasilkan adalah:

$$
P_{1}=\frac{1}{2} \times 2 \text { jam } \times 70 \mathrm{watt}=70 \mathrm{watt} . j \mathrm{jam}
$$

Nilai ini dapat diestimasi sama dengan kapasitas listrik yang dihasilkan pada jam 16.00 - 18.00, yakni 70 watt.jam, sehingga total energi yang dihasilkan pada dua area tersebut adalah 140 watt.jam.

2. Pada pukul 8.00 - 16.00 dapat diestimasi memiliki nilai rata-rata daya 75 watt. Dengan demikian, kapasitas listrik yang dihasilkan adalah:

$$
P_{2}=8 \text { jam } \times 75 \mathrm{watt}=600 \mathrm{watt} . \mathrm{jam}
$$

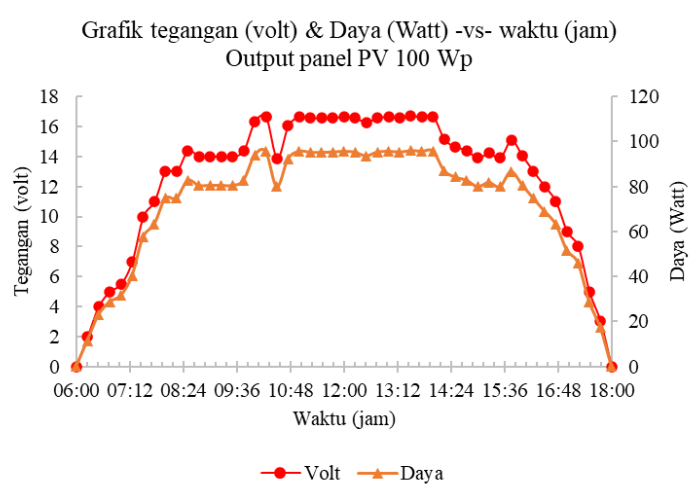

Gambar 3. Grafik rata-rata daya (watt) vs waktu (jam)

Dengan demikian, kapasitas energi listrik yang dihasilkan dalam sehari adalah:

$$
\begin{gathered}
E_{\text {total }}=140 \mathrm{watt} . \mathrm{jam}+600 \mathrm{watt} . \mathrm{jam} \\
=740 \mathrm{watt} . \mathrm{jam}
\end{gathered}
$$

atau sama dengan $0,74 \mathrm{kWh}$.

Setelah mengamati potensi energi listrik yang dihasilkan oleh panel surya, selanjutnya dilakukan pengujian terhadap pengisian daya listrik ke sistem penyimpanan energi, baterai.

\section{B. Pengisian daya baterai}

Baterai Lead Acid dipilih karena performanya yang baik dan kemudahan dalam hal perawatan. Disamping itu, baterai ini juga mudah diperoleh dipasaran, sehingga dalam hal pergantian akan lebih memudahkan pengguna. Selanjutnya, baterai dengan spesifikasi tegangan 12 volt dan kapasitas 70 Ah dilakukan uji pengisian daya menggunakan modul tenaga surya, seperti ditunjukkan pada gambar 4 . 


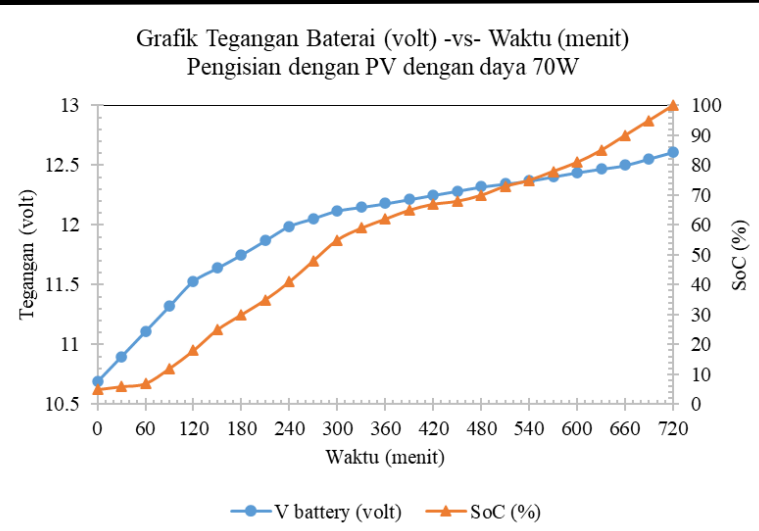

Gambar 4. Grafik pengisian daya baterai dengan panel surya

Pengisian daya dengan solar panel memerlukan waktu 720 menit atau 12 jam. Hal ini diperoleh pada daya maksimum PV yakni 70 watt, sebagaimana grafik pada Gambar 3, pada kondisi cuaca yang cerah. Jika daya yang dihasilkan setengahnya, atau 32 watt, yakni disaat cuaca cendrung berawan, maka pengisian daya sampai baterai penuh dapat mencapai 26 jam.

\section{Pengosongan daya baterai}

Selanjutnya, dilakukan pengujian penggunaan baterai. Pengujian ini dilakukan dengan cara menghubungkan output inverter pada sistem PV dengan daya sebesar 500watt.

Dari grafik pengujian pengosongan baterai diatas dapat diperoleh data bahwa pengosongan dengan menggunakan daya beban $500 \mathrm{~W}$, mampu bertahan selama 100 menit, atau 1 jam 40 menit.

Dalam penerapannya, State of Charge pada baterai tidak boleh sampai level $0 \%$. Hal ini berpengaruh pada daya tahanan baterai untuk penggunakan dalam jangka waktu lama. Berdasarkan referensi [12] batas kapasitas baterai yang harus disisakan adalah $20-30 \%$.

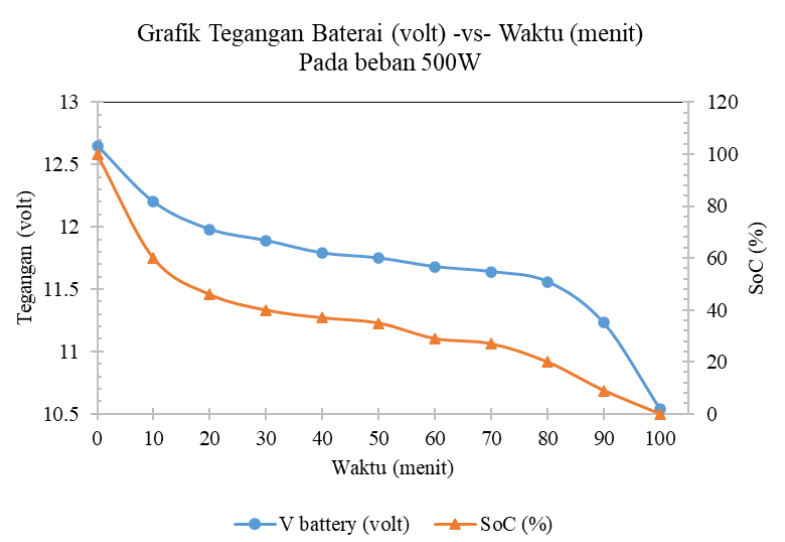

Gambar 5. Grafik pengosongan baterai dengan beban berdaya 500 watt

Dengan melakukan perbandingan antara perhitungan estimasi awal daya yang dapat dihasilkan panel surya maupun hasil pengukuran, maka dapat diketahui bahwa terdapat perbedaan diantara keduanya. Dalam estimasi awal energi yang dapat diperoleh dari panel surya dengan daya maksimum 100Wp diperoleh daya sekitar 0,32 kWh. Sementara dalam pengukuran Gambar 3 diperoleh $0,74 \mathrm{kWh}$, dimana rata-rata pancaran sinar matahari di provinsi Jambi selama 10 jam per hari. Hal ini dapat dipengaruhi oleh bilangan Panel Generation Factor yang dimliki oleh panel surya.

Dengan demikian, kita dapat menentukan dan mengestimasi persentase penghematan energi yang dapat diperoleh, sebagai berikut:

$$
\% \text { penghematan energi }=\left(\frac{\text { Energi } P V(k W h)}{\text { Energi diperlukan }(k W h)}\right) \times 100 \%
$$

$$
\frac{0,74}{4,9} \times 100 \%=15,1 \%
$$

Jika dikonversi ke biaya, maka 15,1\% sama dengan Rp30.200,-.

Untuk kondisi kedua, disaat energi yang dihasilkan solar panel 0,32 kWh per hari, maka:

$$
\frac{0,32}{4,9} \times 100 \%=6.53 \%
$$

Nilai konversi 6.53\% sama dengan Rp 13.060,-.

Dengan demikian, menerapkan sistem energi cadangan berbasis panel surya pada rumah pelanggan listrik berdaya 900 watt dapat menghemat penggunaan listrik $6,53 \%$ sampai dengan $15,1 \%$ atau berturut - turut setara dengan menghemat $\mathrm{Rp} 30.200$ dan $\mathrm{Rp}$ 13.060. Disamping keuntungan tersebut, penggunaan sistem energi listrik tenaga surya ini dapat digunakan sebagai langkah awal meningkatkan implementasi EBT di provinsi Jambi.

\section{KESIMPULAN DAN SARAN}

Sebagai kesimpulan, sistem tenaga surya sebagai energi cadangan untuk pelanggan listrik berdaya 900watt telah dibangun. Dengan menggunakan PV panel $100 \mathrm{Wp}$ dan sistem baterai 70 Ah 12 volts, dalam pengujian di skala laboratorium diperoleh potensi penghematan energi listrik sebersar 6,53\% sampai 15,1\% atau setara dengan Rp 13.060 sampai Rp 30.200 per bulan. Penerapan ini kedepannya menjadi salah satu cara untuk mengurangi ketergantungan akan energi listrik konvensional maupun sebagai usaha untuk meningkatkan penerapan EBT.

\section{REFERENSI}

[1] L. E. B. L. E. Bien, I. Kasim, and W. Wibowo, "Perancangan sistem hibrid pembangkit listrik tenaga surya dengan jala-jala listrik PLN untuk rumah Perkotaan," J. Tek. Elektro, vol. 8, no. 1, 2013.

[2] M. R. Wicaksana, I. N. S. Kumara, I. A. D. Giriantari, R. Irawati, P. K. Energi, and D. Mineral, "Unjuk Kerja Pembangkit Listrik Tenaga Surya Rooftop 158 kWp Pada Kantor Gubernur Bali,” vol. 6, no. 3, pp. 107-113, 2019.

[3] F. Hafiz, A. R. De Queiroz, and I. Husain, "Multi-stage stochastic optimization for a PV-storage hybrid unit in a household," 2017 IEEE Ind. Appl. Soc. Annu. Meet. IAS 2017, vol. 2017-Janua, pp. 1-7, 2017, doi: 10.1109/IAS.2017.8101704.

[4] A. K. Srivastava, A. A. Kumar, and N. N. Schulz, "Impact of distributed generations with energy storage devices on the electric grid," IEEE Syst. J., vol. 6, no. 1, pp. 110-117, 2012, doi: 10.1109/JSYST.2011.2163013. 
[5] C. Cavallaro, S. Musumeci, C. Santonocito, and M. Pappalardo, "Smart Photovoltaic UPS System for Domestic Appliances," 2009 Int. Conf. Clean Electr. Power, ICCEP 2009, pp. 699-704, 2009, doi: 10.1109/ICCEP.2009.5211952.

[6] M. Isnen, S. Kurniawan, and E. Garcia-Palacios, "A-SEM: An adaptive smart energy management testbed for shiftable loads optimisation in the smart home," Meas. J. Int. Meas. Confed., vol. 152, p. 107285, 2020, doi: 10.1016/j.measurement.2019.107285.

[7] C. Iclodean, B. Varga, N. Burnete, D. Cimerdean, and B. Jurchiş, "Comparison of Different Battery Types for Electric Vehicles," IOP Conf. Ser. Mater. Sci. Eng., vol. 252, no. 1, 2017, doi: 10.1088/1757899X/252/1/012058.

[8] R. K and B. Y. Dewantara, "Perhitungan Kebutuhan Daya Listrik untuk Penggerak Perahu Nelayan Bertenaga Surya," Cyclotron, vol. 3, no. 1, pp. 1-4, 2020, doi: 10.30651/cl.v3i1.4305.
[9] D. L. Pangestuningtyas, Hermawan, and Karnoto, “Analisis Pengaruh Sudut Kemiringan Panel Surya Terhadap Radiasi Matahari Yang Diterima Oleh Panel Surya Tipe Larik Tetap," Transient, vol. 2, pp. 0 7, 2013.

[10]H. E. Hardianto and R. S. Rinaldi, "PERANCANGAN PROTOTYPE PENJEJAK CAHAYA MATAHARI PADA APLIKASI PEMBANGKIT LISTRIK," J. Ilm. Foristek, vol. 2, no. 2, pp. 208215,2012

[11]S. Sepdian, "Analisis Tekno-Ekonomi Pengembangan Photovoltaic Pada Gedung Politeknik Jambi," J. Elektron. List. dan Teknol. Inf. Terap., vol. 2, no. 1, pp. 26-29, 2020.

[12]S. Sepdian and S. Syafii, "Simulasi Tekno-Ekonomi Pengembangan Photovoltaic pada Gedung," J. Surya Tek., vol. 5, no. 01, pp. 1-5, 2017. 